\title{
Food (Glutonic) Linguocode in the Typology of Cultural Codes
}

\author{
Zhanna Koloiz ${ }^{1, *}$
}

\author{
${ }^{I}$ Kryvyi Rih State Pedagogical University, Ukraine \\ "Corresponding author.Email: koloiz.zv@gmail.com
}

\begin{abstract}
The article deals with the concept of "cultural code", actual approaches to the classification of the codes within the cultural framework. This work also represents the general typology of cultural codes, which can be considered as verbal or nonverbal. The last includes visual, auditory, tactile, odorous subtypes. The verbal type is qualified through exponential signs of material and nonmaterial (intellectual) items of culture. Taking into consideration differences of the sings which are culturally marked, the linguocodes are divided into 1) national and cultural linguocode; 2) international and cultural linguocode; 3) subcultural linguocode. We also investigate partial branching of the national and cultural linguocode, which includes biotic and abiotic subtypes. The biotic sybtype comprises of anthropic and organic (animal / plant) linguocodes. The abiotic sybtype unites natural and artefactual linguocodes. Food, which is also called glutonic, linguocode belongs to the subtypes of artifactual verbal national and cultural linguocode. The glutonic linguocode together with other codes which are not being discussed in the given research, continues the classification scheme, in particular provides a thematic taxonomy. This code carries the system of conventional signs which have balanced themselves in the language system after approbation in the oral practice of nutrition. The glutonic linguocode provides the connection between the sign and the meaning which promotes the transfer of glutonic nomination (plane of expression) into the area of meaning (plane of content).
\end{abstract}

Keywords: cultural code, verbal / nonverbal code, linguocode, national and cultural / international and cultural / subcultural linguocode, biotic / abiotic linguocode, anthropic / organic (plant / animal) linguocode, natural / artefactual linguocode, food (glutonic) linguocode.

\section{1. ВСТУП}

Термінологічне словосполучення "код культури" непохитно стабілізувалося в науковому обігові, розпросторилося в семіотичній, соціологічній, культурологічній, лінгвістичній i, відповідно, у соціолінгвістичній, етнолінгвістичній, лінгвокультурологічній і т. ін. царинах. Попри посилений інтерес 3 боку дослідників, наявність різних підходів і різних аспектів аналізу, численних наукових доробків наразі окреслено чимало проблемних моментів, пов'язаних не лише 3 осмисленням і дефініцією наукової категорії, але й також із побудовою більш виваженої, усебічно обміркованої типології.
Актуальність праці зумовлена об'єктивною потребою впорядкувати розмаїття глибинних елементів культурного простору, іменованих культурними кодами, систематизувати сукупність мовних засобів-репрезентантів за парадигматичним принципом, установити релевантні відмінності в їх використанні. Пропоноване дослідження грунтоване на таксономії культурних кодів, 3-поміж яких i вербальний, у межах якого об’єднано парадигми на основі знака-носія культури, що вможливить окреслення параметрів національно-культурного коду загалом, його розгалуження відповідно до тих чи тих тематичних характеристик, які закріпилися у вигляді мовних знаків. 
Мета - з'ясування місця харчового лінгвокоду в типології кодів культури через застосування парадигматичного підходу, що, з одного боку, поглиблює типологію культурних кодів, з іншого, - окреслює вектор дослідження харчового, або глютонійного, коду, стає точкою відліку для подальшого студіювання глютонійних найменувань. Такі найменування $\epsilon$ відносно новими об'єктами наукових студій, тривалий час залишалися без належної уваги дослідників, оскільки, так би мовити, актуалізували тілесні, а не духовні потреби людини. Наразі вербальні знаки, пов'язані 3 харчовою культурою народу, потребують різноаспектного вивчення, що сприятиме виваженій організації цілісної структури й установленню зв'язків і відношень між ії елементами.

Теоретично-оглядовий характер статті зумовив використання таких методів: метод структурносистемного аналізу, яким, власне, послуговуються задля теоретичного розроблення проблеми; метод термінологічного аналізу (для дефініції ключових понять дослідження); описовий метод (для інвентаризації, таксономії й інтерпретації актуалізованих понять).

\section{2. ВЕКТОР НАУКОВИХ ПОШУКІВ}

Як відомо, код вважають ключовим терміном семіотики, який “узаконює" відповідність між планом вираження і планом змісту того чи того умовного знака, що являє собою матеріально виражену заміну предметів (у широкому витлумаченні) для передавання, збереження й обробки інформації (фр. code < лат. codex “список постанов, збірник”). Інакше кажучи, код являє собою систему розрізнень, у якій А пояснюють як те, що не $\epsilon$ В, C і Д, і навпаки. Саме по собі А нічого не означало б, якби не співвідносилося з іншими символами [1].

Сутність відповідних емпіричних матеріальних знаків-об'єктів, знаків-символів, які сприймаються на чуттєвому рівні через призму інших, уже пізнаних, реалій, їх структурні моделі, диференціація на природні / штучні, мовні / позамовні і т. ін. досліджує не одне покоління науковців. Монографічні й колективні праці, узагальнюючи теоретичний і практичний досвід, репрезентують низку потрактувань (як широких, так і вузьких), з-поміж яких вирізняються й ті, які стосуються вербального вираження. Пор.: код - це “правила мовної системи, згідно 3 якими відбувається "упаковка" інформації в текст і сприйняття повідомлення” [2, р. 179], “сукупність правил чи їхніх обмежень, що забезпечують функціонування природної мови або тієї чи тієї знакової системи” [3]. У такому разі, вочевидь, ідеться не просто про код, а про вербальний, мовний код, лінгвокод як систему комунікативних нормативних конвенцій, домовленостей, стосовно валентності певних знаків із певними семантичними блоками.

\section{1. Поняття "культурний код"}

Дефініція поняття код, 3 одного боку, та поняття культура (лат. culture - “догляд, освіта, розвиток” - “сукупність матеріальних і духовних цінностей, створених людством упродовж його історії; історично набутий набір правил усередині соціуму для збереження його стрійності, злагодженості, суголосності, гармонійності"), 3 іншого, спричинили появу різноаспектних потрактувань понять на зразок код культури чи культурний код.

Варто зауважити, що в науковій царини немає одностайності й щодо співвідношення відповідних понять: їх здебільшого ототожнюють, тому й послуговуються як синонімічними (див. праці Д. Гудкова [4], В. Красних [5] та ін.). I повсякчас апелюють до того, що вони потребують уточнення як категорії гуманітарного дискурсу [6], зокрема лінгвокультурологічного, у межах якого апробоване термінологічне словосполучення лінгвокультурний код, який зазвичай розглядають крізь призму сукупності знань про культуру тієї чи тієї лінгвоспільноти [7].

\section{2. Форми культурних кодів}

Класифікаційна схема культурних кодів свого часу була запропонована М. Толстим під час осмислення проблеми співвідношення мови i культури, зокрема 3 використанням прикладів обряду i ритуалу як «текстів, виражених семіотичною мовою культури» [8, p. 14]. Вона передбачала три «форми» (рис. 1).

У науковому просторі активно підтримуваною $\epsilon$ й класифікаційна схема, що передбачає диференціацію культурних кодів на субстанційні та концептуальні, де виокремлення перших грунтоване на плані вираження (матеріальній, субстанційній природі знаків), других - на плані змісту(матеріальне втілення культурного смислу) $[9$, p. 340], [10, p. 172], [11]. Осмислюючи субстанційно різні набори знаків, використовувані для вираження того чи того змісту (озвучене або написане слово, жест або дію, колір або 
зображення і т. ін.), С. Толста апелює й до системи знаків, об'єднуваних на основі їх значення незалежно від субстанції самих знаків, які й кваліфікує як субстанційні коди [12, pp. 109-110].

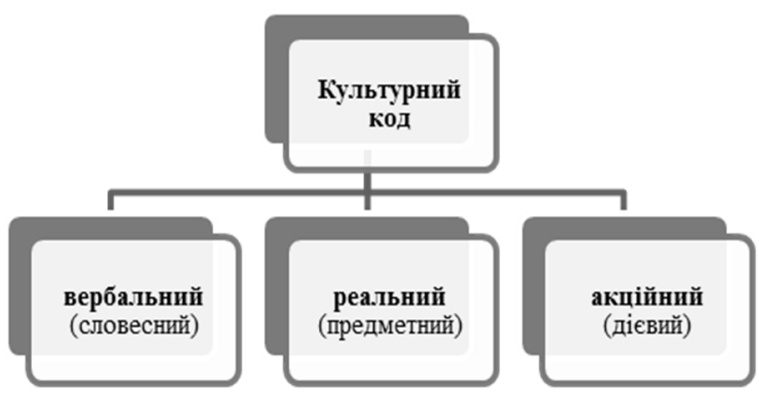

Рисунок 1 Форми культурних кодів (згідно 3 позицією М. Толстого)

Чимало науковців, відштовхуючись від запропонованих диференціацій, прагнули внести ті чи ті корективи, доповнення, уточнення і т. ін. Так, скажімо, Д. Гудков, загалом позитивно оцінюючи запропоновану контекстуально зумовлену (“...виокремлення цих трьох кодів можливе не тільки в обряді й ритуалі, а й узагалі в культурному полі як такому” [4, р. 40]) й схематично представлену класифікацію, висловлює ряд зауважень, основні з яких зводяться до такого твердження: 1) термін “реальний код культури” є надзвичайно широким; 2) одиниці як реального, так і акційного кодів культури можуть вербалізуватися, тобто отримати найменування, стати складниками вербального коду. Це дає підстави розглядати вербальний код культури як основний й узалежнити його до важливих об'єктів наукових проєктів.

\section{3. Загальна типологія культурних кодів}

Лінгвокультурний (мовнокультурний) код як наукова універсалія викликала жваві обговорення й спричинила появу низки спеціальних розвідок, присвячених вивченню культурних факторів, маніфестованих мовними засобами (Н. Андрейчук, Н. Арутюнова, Р. Барт, Д. Гудков, У. Еко, А. Загнітко, М. Ковшова, В. Красних, Ю. Лотман, В. Маслова, В. Пустовалова, С. Руденко, Л. Савченко, О. Селіванова, В. Телія, М. Толстой, Д. Ужченко та ін.). Попри зрозумілість, доступність для сприймання, дохідливість і плану вираження, і плану змісту термін так i не отримав чіткого, тим паче, загальноприйнятого наукового витлумачення.
Науковці в основному апелюють до особливого способу представлення знаків - вербального, диференціюючи в них інформаційний та процедурний компоненти: сукупність мовних одиниць-символів, що актуалізують усталені, узвичаєні знання про культуру, оформлена як вербальне повідомлення, витримане відповідно до встановлених правил.

Не викликає принципових заперечень i твердження про те, що лінгвокультурний код $\epsilon$ лише одним із різновидів культурних кодів [14]. У межах лінгвокультурології таке термінологічне поєднання є виправданим, проте в рамках інших наукових царин, мабуть, доцільніше було б послуговуватися сполученням лінгвокод культури чи то культурний лінгвокод (i за зразком відеокод, аудіокод т. ін.). Пор.: коли йдеться про диференціацію кодів культури залежно від матеріальної природи знаконосіїв, виокремлюють вербальні, візуальні, аудіальні, тілесні, або тактильні, запахові, або одоративні підвиди [2, pp. 68-69], що, власне, групуються навколо двох основних різновидів, як-от: 1) вербальний; 2) невербальний. Схематично це має такий вигляд:

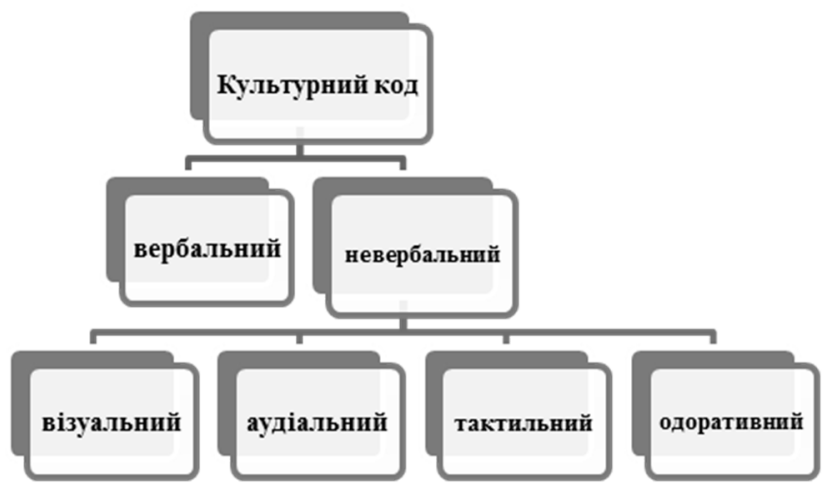

Рисунок 2 Загальна типологія культурних кодів

Цілком очевидним залишається те, що “межа між вербальним і невербальним кодами, не $\epsilon$ герметичною, оскільки елементи останніх часто вербалізуються в суспільному дискурсі" [16] як способові організації інформаційного простору та формування громадської думки. I вербальний, i невербальний різновиди культурного коду мають низку як інтегральних, так і диференційних ознак, на яких ми в межах запропонованої праці не зупинятимемося. Основний акцент зробимо на потрактуванні вербального коду культури (лінгвокультурного коду, культурного лінгвокоду). 


\section{3. КУЛЬТУРНИЙ ЛІНГВОКОД}

Маніфестуючи культуру як простір культурних кодів, усвідомлюваний не через систему координат, а через відношення, установлювані між об'єктами, В. Маслова вдається до потрактування коду через концептуальну метафору “контейнер”: код - це “контейнер", у якому різні мовні сутності отримують різні культурні смисли [17]. Услід за дослідницею запропонуємо і власне метафоричне витлумачення.

Культурний лігвокод являє собою так зване спеціальне сховище, “музей”, у якому зібрано, упорядковано й експоновано “колекцію” мовних знаків, репрезентантів матеріальної i нематеріальної (духовної) культури, який зберігає правила співвіднесення культурно значущої інформації з певними знаками-символами. Це дає підстави вести мову про нижчі сходинки ієрархічної побудови типології вербального коду культури, як-от: 1) лінгвокод як експонент матеріальної культури; 2) лінгвокод як експонент нематеріальної (духовної) культури. Своєю чергою, кожен із різновидів репрезентує сукупність різних кодів, виокремлюваних на основі тих чи тих критеріїв.

Наразі спостерігаємо чимало проблемних моментів у питаннях типології як кодів культури загалом, так і лінгвокультурних кодів зокрема: брак більш-менш адекватної класифікаційної схеми пов'язують із відсутністю єдиної метамови, термінологічними лабіринтами кодового простору загалом та лінгвокодового зокрема. Кожна загальнонаціональна культура передбачає сукупність різних лінгвокодів, репрезентуючи багаторівневу структуру, елементи якої перебувають у синтагматичних і парадигматичних відношеннях.

\section{1. Таксономія вербального коду культури}

Якщо мову називають культурним кодом нації (сукупність знаків, що виступають своєрідними інформаційними маркерами, забезпечує адекватне сприйняття, відповідну реакцію й національнокультурну ідентифікацію), а загальнонаціональна культурна парадигма поєднує як власне національне, так і інтернаціональне, то, вочевидь, елементи будь-якого культурного лінгвокоду не $\epsilon$ однотипними, зберігають інформацію (у різних пропорціях) про “свої” і “чужі” матеріальні й духовні цінності, про культуру нації і людства загалом. Те, що ми кваліфікуємо як власне національне, також має певні відмінності: у межах кожної “суспільної більшості” функціонують певні соціальні групи з відмінними стандартами, моделями поведінки, системою цінностей i символів і т. ін., іменовані здебільшого субкультурами. Подекуди в науковому просторі натрапляємо на терміносполучення “субкод культури”, використовуване в широкому потрактуванні - зі значенням “різновид культурного коду” [18], [19]. Пор: “Культурний код може поділятися на субкоди. Ієрархія субкодів при цьому є багаторівневою. Система культурних кодів 3 iї “вертикальними” і “горизонтальними” відношеннями являє собою образну систему культури" [20].

На думу П. Донця, на основі рівневого характеру культури в типології кодів доречно диференціювати субкультурний різновид, що протиставляється супракультурному та національно-культурному [16]. Загалом позитивно оцінюючи такий підхід і беручи до уваги увесь репертуар знаків-символів, правил їх використання, походження і т. ін. у національному культурному просторі, який $\epsilon$ складовою світового, поєднує національне (етнічно неповторне, національно особливе) й інтернаціональне (загальнолюдське), зрозуміле чи то широкому колу носіїв мови і культури, чи то окремим соціальним групам, запропоновану вище загальну типологію культурних кодів, зокрема вербальний різновид, розгалужуємо на такі підвиди: 1) національно-культурний лінгвокод; 2) інтернаціонально-культурний лінгвокод; 3) субкультурний лінгвокод. Схематично це матиме такий вигляд:

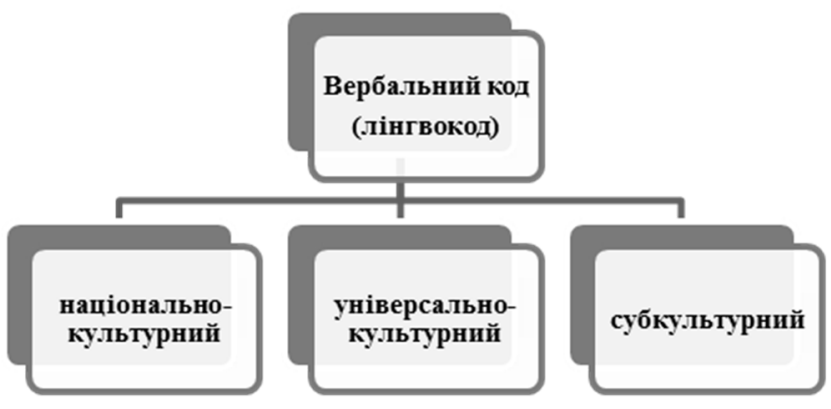

Рисунок 3 Таксономія вербального коду культури (на основі знака-носія культури)

Не викликає жодних спростувань твердження про те, що зацікавлення науковців викликає передовсім національно-культурний лінгвокод, який експонує знаки-символи національної 
культури чи субкультури. Пор.: “під кутом зору лінгвокультурології і теорії міжкультурної комунікації інтерес викликають перш за все знаки національно-культурного рівня, а також елементи субкультурних кодів, що відомі більшості або принаймні великій кількості носіїв відповідної культури" і які можуть диференціюватися за соціальними, часовими, регіональними і т. ін. ознаками” [16].

\section{2. Національно-культурний лінгвокод $i$ його оиференціація}

Варто зауважити: подекуди до важливих класифікаційних критеріїв типологізації культурних кодів уналежнюють означуваність (“те, що знак означає”) й виокремлюють такі різновиди: 1) предметний; 2) абстрактний; 3) подієвий (рос. событийный); 4) акційний [16]. Така диференціація постає як результат критичного осмислення основних культурних кодів, запропонованих В. Красних (соматичний, просторовий, часовий, предметний, біоморфний, духовний [5, p. 233]. Вона, безсумнівно, перегукується з класифікацією М. Толстого, однак у ii структурі відсутній той різновид, який вважають найголовнішим - вербальний. Окрім того, попри намагання з'ясувати сутність кожного iз представлених різновидів, витлумачити їх змістове наповнення, спільні і відмінні ознаки, точки перетину, подальше структурування [16] деякі моменти, як нам видається, так і залишилися проблемними, спонукають до подальших дискусій. Наприклад, предметний різновид, на думку вченого, що об'єднує біоморфні і речовинні знаки, відмінною ознакою яких є використання іконічних засобів, протиставляється абстрактному, до якого без чітких обгрунтувань уналежнено час, місце, напрям, колір, цифри. Атрибутив предметний є похідним від предмет, що означає, з одного боку, “будь-яке конкретне матеріальне явище, що сприймається органами чуття”, з іншого, - “логічне поняття, що становить зміст думки, пізнання і т. ін.”, а відтак абстрактний ("який виник у результаті абстрагування”) опозиціонує до конкретний (“який існує реально; цілком точний, предметно визначений”).

Попри намагання формально диференціювати подієвий (охоплює як регулярно повторювані, так і унікальні (“знакові”) події) й акційний (охоплює “знакові” дії, ритуали, форми “демонстративної” поведінки) різновиди запропоноване розмежування має вигляд непереконливого, бездоказового, містить певні суперечності (пор.: в українській мові слово акційний = дієвий, а дієвий і подієвий - етимологічно споріднені; у російській - у XX столітті замість “событный”, яке вийшло 3 ужитку, з'явився дериват “событийный”, що відповідає сучасному значенню слова "событие” “имеющий отношение к событиям, действиям” або “богатый событиями, действиями” (“действие” наразі розуміють як протиставлення “бездействию”, відсутності активності).

Доволі популярною є класифікація культурних кодів загалом та вербальних різновидів зокрема на основі тематичного критерію - об'єднання в межах тієї чи тієї теми [10]. Сукупність тематичних різновидів, запропонованих у працях В. Красних (соматичний, просторовий, часовий, предметний, біоморфний, духовний), модифікують у напрямку до “вдосконалення”, доповнюють, конкретизують, розгалужують, перейменовують [27], а подекуди й переформатовують [16]. У різних доробках тематична класифікаційна схема передбачає різні “набори”. Узагальнений перелік передбачає низку підвидів, які іноді $\epsilon$ різними назвами одного й того ж поняття чи то співвідносяться як загальне / часткове, родове / видове і т. ін.: космогонічний, астрономічний, біоморфний, флороморфний, фітоморфний, рослинний, зооморфний, анімалістичний, природний, природоморфний, природно-ландшафтний, ландшафтногеографічний, антропоморфний, антропний, агентивний, предметний, артефактний, предметно-артефактний, об'єктний, речовий, архітектурний, соматичний, тілесний, харчовий, просторовий, числовий, квантативний, акційний, релігійний, міфологічно-релігійний, весільний, духовний тощо (див. праці Ю. Башкатової, Д. Гудкова, . Донця, I. Дукальсьої, Є. Капелюшник, М. Ковшової, В. Маслової, В. Пустовалової, Л. Савченко, Х. Сарач, а також [28]). Такий “список”, на думку науковців, залишається відкритим для поповнення, сама ж класифікаційна модель потребує, як нам видається, більш чіткого порядку, зумовленого правильним, планомірним розташуванням та взаємозв'язком відповідних елементів.

У руслі досліджуваної проблеми продовжимо розгалуження типології вербального коду культури, зокрема національно-культурного різновиду, беручи до уваги те, що будь-яка мовна одиниця (знак) є носієм особливого, виняткового, унікального значення, детермінованого тим культурним кодом, якому вона належать і сприяє ідентифікації відповідної культури. 
До лінгвального простору національнокультурного коду належить система мовних знаків, у яких зашифровано (“засекречено”, приховано) інформацію про особливості матеріального й духовного життя етносу: з одного боку, ці знаки передають знання, повідомляють про реальні, предметно визначені, емпіричні (грунтовані на досвіді) об'єкти, 3 іншого, - про абстрактні об' єкти, поняття, які виникли у процесі пізнання внаслідок абстрагування. Це дає підстави диференціювати мовні знаки на такі, що уналежнені чи то до емпіричного (конкретнооб'єктного), чи то до абстрактного лінгвокодів, тобто такі мовні знаки містять відомості про результат узагальнення суттєвих ознак конкретних / абстрактних об'єктів дійсності.

3 огляду на мету в рамках запропонованої наукової розвідки на особливостях другого підвиду не зупинятимемося взагалі. Що стосується першого - емпіричного (конкретно-об'єктного) лінгвокоду, - то від нього можна відгалузити дві гілки на зразок: 1) біотичний лінгвокод (від грец. bios - “життя”, що являє собою сукупність мовних знаків, що зберігають і передають інформацію про живе; традиційно послуговуються терміном біоморфний (грец. morphē - “форма"), який, гадаємо, не зовсім адекватно відбиває суть відповідного поняття; пор.: за цим зразком утворені й інші, як-от антропоморфний (від грец. anthrōpomorphos _ “ “людиноподібний”); 2) абіотичний лінгвокод (префікс $a$ - означає заперечення, відсутність ознаки, засвідченої в корені), що являє собою сукупність мовних знаків, які зберігають i передають інформацію про неживе, те, що позбавлене життя.

Подальше розгалуження біотичного лінгвокоду передбачає виокремлення таких підвидів: а) антропний (грец. anthrōpos - “людина") сукупність мовних знаків, що зберігають i передають інформацію про людину; б) органічний - сукупність мовних знаків, що зберігають i передають інформацію про рослинний і тваринний світи, - у межах якого чітко простежуємо диференційну ознаку, що уможливлює подальше групування навколо чи то рослинного, чи то тваринного лінгвокодів.

Від абіотичного лінгвокоду так само можна відгалузити два підвиди, як-от: а) натурфактний; б) артефактний (лат. artefactum - “штучно зроблений”), де перший об'єднує сукупність мовних знаків, що зберігають i передають інформацію про природні об'єкти, тобто ті, які створені природою, другий - сукупність мовних знаків, що зберігають і передають інформацію про штучні об'єкти, тобто ті, які є результатом творчої діяльності людини. Схематично це матиме такий вигляд:

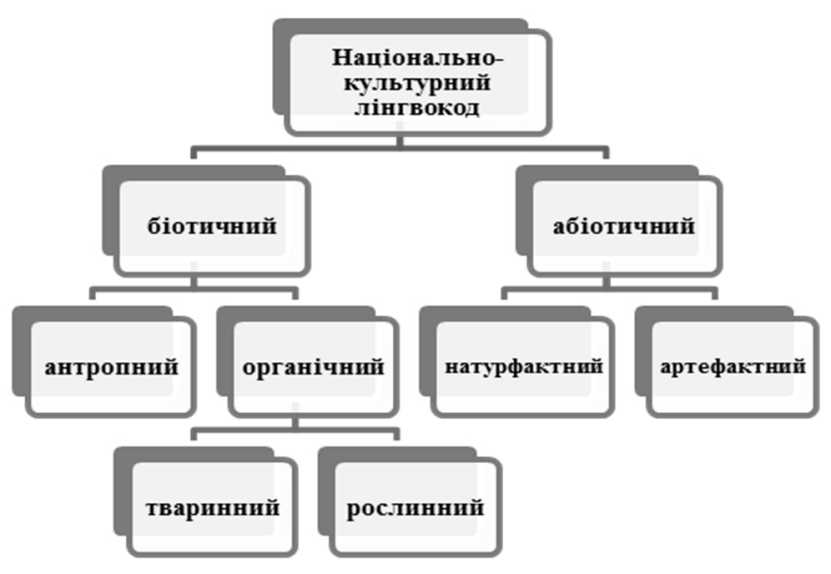

Рисунок 4 Таксономія національно-культурного лінгвокоду

Цілком очевидно, що кожен із диференційованих підвидів, зокрема антропний, натурфактний, артефактний, інтегрує елементи, які характеризуються як спільними, так і відмінними характеристики, що сприятиме побудові деталізованої класифікації. Наразі ж нам залишається визначити місце так званого харчового, або глютонійного, лінгвокоду в типології вербального коду загалом та національно-культурного лінгвокоду зокрема.

\section{3. Харчовий, або глютонійний, лінгвокод у типології вербального коду}

Не викликає жодних заперечень твердження про те, що їжа (харчі) являє собою один із найважливіших i найдавніших елементів матеріальної культури етносу, оскільки $\epsilon$ необхідною умовою функціонування людського організму. А тому цілком закономірно, що сукупність знаків, зокрема й вербальних, які маніфестують “образи” продуктів харчування віддавна викликає науковий інтерес, що впродовж останніх десятиліть лише посилюється.

Попри суттєві здобутки у відповідній царині наразі спостерігаємо різнобій і у підходах до розв'язання проблеми, й $\mathrm{y}$ виробленні загальноприйнятого термінологічного апарату. Так, скажімо, у науковому обігові для позначення одного й того ж поняття як зарубіжні, так i вітчизняні вчені послуговуються неоднаковою 
термінологією, наприклад: код, пов'язаний із харчовою культурою, кваліфікують як: харчовий, кулінарний, гастрономічний, кулінарногастрономічний, аліментарний, глютонічний (див. праці [9, р. 340], [25], [26] та ін.). Кожен із науковців, осмислюючи наявну термінологію, пристаючи до певної позиції чи то пропонуючи власну, прагне навести переконливі аргументи, чому, власне, такому, а не іншому термінові він віддає перевагу або вдається до його (ïx) потрактування. Пор.: “Для позначення харчової культурної традиції оперуємо терміном предметно-глютологічний СКК. Як відомо, терміном глютономен позначають назви сировини, напівфабрикатів, страв, харчових продуктів і консервів, напоїв, номінації харчів без вказівки на склад. Предметно-глютологічний СКК тісно пов'язаний зі смаковим. Базовими концептами й концептуальними символами в цьому коді виступають компоненти для позначення продуктів харчування й способів приготування їжі...” [24]. Щоправда, на термін глютономен (глютонім, глютонія) натрапляємо доволі рідко, окрім того, подекуди науковці акцентують на "непрозорості" його значення, додаткових конотаціях (анг. gluttony “ненажерливість”) і відсутності пояснення у спеціальних словниках, довідниках і т. ін. [23]. На думку А. Олянича, “глютонімами варто іменувати власне знаки харчів і їх компонентів” [22].

В українській мові віддавна для позначення “того, що споживають, їдять і п’ють, їстівних припасів” використовують слово харч, яке запозичено з арабської мови через посередництво турецької [15]. Звідси, відповідно, логічно було б і підвид артефактного лінгвокоду кваліфікувати як харчовий. 3 огляду на глобалізаційні процеси прийнятним вважаємо термін, спродукований від слова глютонія (глютоній-а + -н-ий), тобто глютонійний (мабуть, випадково співзвучне зі словом глитати, що походить від лат. glūtus “горлянка”, glūtio - “ковтаю” [21, p. 525]). Пор.: гастрономічний < гастрономія (фр. gastronomie < грец. gastēr (gastros) - “шлунок” і nomos - “закон” - “сукупність харчових продуктів високоякісного приготування; вишуканість, тонкий смак у їжі; знання і розуміння тонкощів кулінарії” [21, p. 480]; кулінарний < кулінар (лат. culı̄nārius - “кухонний” < culīna - “кухня, їжа" - "мистецтво приготування страв, а також загальна назва страв” [13].

Харчовий, або глютонійний, лінгвокодод - один iз підвидів артефактного вербального національно-культурного коду, що оперує сукупністю мовних знаків, які експонують інформацію про особливості харчової культури того чи того етносу, визначають набір певних образів і символів, пов'язаних із еталонними, стереотипними уявленнями, що, своєю чергою, сприяє національній ідентифікації. Адже, як відомо, будь-яка мова є відображенням культури іiі носіїв, надає в їх розпорядження засоби для кодування й декодування важливої, актуальної інформації.

Глютонійний лінгвокодод транслює систему конвенційних знаків, які стабілізувалися в мовній системі після апробації в узусній практиці харчування. Він забезпечує зв'язок між знаком i значенням, сприяє переведенню глютонійної номінації (план вираження) у площину смислу (план змісту). Його можна декодувати тоді, коли мати у своєму придбанні, у “власності”, відповідний лексичний запас і набір відповідних (відомих) символів [40]. Наприклад: Свининка на кісточці, жменька квасольки, / Грибочки, капуста, штук три барабольки, / Морквинка, буряк, часничок $i$ перчинка, / Листочок лавровий, укропу стеблинка, / Солодкого периюю й селери частинка, / Петрушечки трішки, та солі краплинка, / Одна ичибулинка й иматочок сала, / Щоб злотомедально та страва сіяла, / помідори додати у горщик, / I вийде - смачнющий украӥнський борщик! / Тепер треба взяти сметани гладущик, / Та миску пампушок гарячих пахущчих. / Налити в тарілку духмяную страву, / За смаком додати сметанку в приправу. / Та хлюпнуть у чарочку грам n'ятдесят, / I в шлунок відправить вогненний заряд. / Крякнути, хукнуть $i$ два огірочки, / Що перед обідом дістали ви з бочки, / Зжувати повільно. Й тепер вже, тихенько, / Хоч слина й клекоче, та ви - помаленьку, / Щоб ваше бажання - сягнуло зірок, / (Бо в шлунку - самотньо вола огірок), / У ложку здорову бориу наберіть, / I райський нектар той у рот покладіть... / Прожуйте, смакуючи, ци ніжну пампушку / Вкусіть, як хижак - свою здобич-звірюшку. / I знову процес із борщем повторіть - / Хай вічністю стане солодкая мить!... (О. Зубрій. «Борщ»). Такий так званий «глютонійний текст» демонструє не просто самобутній унікальний рецепт приготування українського борщу, процес його споживання, який представлено не лише як процес задоволення фізіологічних потреб людини, але й як своєрідний національно-культурний простір, у якому, здавалося б, звичайна страва стає незвичайною, а сам мовний знак набуває символьного значення. Запропонована “технологія” приготування й споживання українського борщу, з одного боку, а 3 іншого, - 
здатність оцінити його вишуканий смак, що великою мірою залежить від інгредієнтів, представлених глютонійними найменуваннями, інформація про які зберігається в "національнокультурному сейфі”. Аби “заволодіти” нею, потрібно отримати доступ, дешифрувати спеціальний код, пройти ідентифікацію, у результаті якої й відбуватиметься диференціація на “своїх" і “чужих".

\section{4. ВИСНОВКИ}

$\begin{array}{ccc}\text { Насамкінець } & \text { зауважимо, } & \text { глютонійні } \\ \text { найменування } & \text { відбивають } & \text { специфіку }\end{array}$ національного світосприйняття, етносвітогляду, а система образних i символічних смислів, пов'язаних із традиціями харчування, експонує особливий глютонійний код культури, транслює “прислівні етнокадри”, що зазвичай $\epsilon$ результатами компресії, ущільнення інформації 3 окремих епізодів людського життя. Такі маргінальні знаки потребують осмислення крізь призму і мови, і культури, задля адекватного потрактування змушують представника тієї чи тієї лінгвоспільноти орієнтуватися як у сфері коду (мови), так і у сфері інформації, що передає цей код (культури). У зв'язку 3 цим нагальною потребою залишається розв'язання проблеми відтворення, реконструкції культурних кодів, зокрема й глютонійного, 3 урахуванням напрацювань міфології, етнографії, фольклору, народного мистецтва і т. ін.

Усебічне дослідження глютонійного коду культури, яка законсервувала в собі архаїчні елементи світогляду, потребує парадигматичного підходу, нового і теоретичного, і практичного осмислення багатьох фактів, їх системної, порівняльно-історичної інтерпретації, спеціальної лексикографічної праці.

\section{BHECOK АBTOPA}

Окрім того, що в межах запропонованої праці 3'ясовано сутність поняття “культурний код”, маніфестовано актуальні підходи до класифікації кодів культури, представлено авторське бачення загальної типології культурних кодів, яка передбачає вербальний / невербальний різновиди 3 подальшою диференціацією останнього на: візуальний, аудіальний, тактильний, одоративний підвиди. Вербальний різновид кваліфіковано крізь призму знаків-експонентів матеріальної / нематеріальної (духовної) культури. На основі розрізнення знаків-носіїв культури у межах культурного лінгвокоду систематизовано: 1) національно-культурний лінгвокод;

2) інтернаціонально-культурний лінгвокод; 3) субкультурний лінгвокод. Репрезентовано часткове розгалуження національно-культурного лінгвокоду, що передбачає: 1) біотичний; 2) абіотичний підвиди; перший об'єднує: a) антропний; б) органічний (тваринний / рослинний) лінгвокоди; другий: а) натурфактний; б) артефактний лінгвокоди. Харчовий, або глютонійний, лінгвокодод уналежнено до підвидів артефактного вербального коду. Глютонійний лінвокод разом із іншими, не розглядуваними в межах запропонованої розвідки, продовжує класифікаційну схему, зокрема забезпечує тематичну таксономію.

\section{REFERENCES}

[1] U. Eko, Otsutstvuyuschaya struktura. Vvedenie v semiologiyu, Sankt-Peterburg, 2006, p. 72.

[2] E.E. Brazgovskaya, Semiotika. Yazyiki i kodyi kulturyi, Moskva, 2019.

[3] A.P. Zahnitko, Slovnyk suchasnoi linhvistyky: poniattia i terminy, Donetsk, 2012, vol. 2, p. 51.

[4] D.B. Gudkov, Edinitsyi kodov kulturyi: problema semiotiki, in: Yazyik, soznanie, kommunikatsiya, iss. 26, Moskva, 2004, pp. 3950 .

[5] V.V. Krasnyih, Etnopsiholingvistika i lingvokulturologiya, Moskva, 2002.

[6] N.G. Merkulova, Genezis, definitsiya i tipologicheskie harakteristiki ponyatiya "kulturnyiy kod" v gumanitarnom diskurse, Observatoriya kulturyi 6 (2015), 80-84. DOI: https://doi.org/10.25281/2072-3156-2015-0-680-84

[7] I.E. Bryiksina, N.I. Suhanova, Lingvokulturnyiy kod kak sovokupnost znaniy o kulture yazyikovoy obschnosti, in: Filologicheskie nauki. Voprosyi teorii i praktiki, Tambov, 2014, 6 (36), part II, pp. 34-36.

[8] N.I. i S.M. Tolstyie, Slavyanskaya etnolingvistika: voprosyi teorii, Moskva, 2013.

[9] E.L. Berezovich, Yazyik i traditsionnaya kultura: Etnolingvisticheskie issledovaniya, Moskva, 2007. 
[10] M.L. Kovshova, Lingvokulturologicheskiy metod vo frazeologii: Kodyi kulturyi, Moskva, 2013.

[11] E.A. Homyakov, Kodyi kulturyi v zhargonnoy frazeologii, Izvestiya vyisshih uchebnyih zavedeniy. Povolzhskiy region. Gumanitarnyie nauki 3(31) (2014) 152.

[12] I.V. Masliaieva, Nazvy strav u suchasnomu khudozhnomu movlenni: strukturnosemantychnyi ta funktsionalno-stylistychnyi aspekty, Kryvyi Rih, 2018.

[13] Etymolohichnyi slovnyk ukrainskoi movy, Kyiv, 1989, vol. 3, p. 134.

[14] N. Andreichuk, Zastosuvannia termina kod v antropokulturnii linhvistytsi, Visnyk Natsionalnoho universytetu "Lvivska politekhnika". Seriia "Problemy ukrainskoi terminolohii” 648 (2009) 113-117

[15] Etymolohichnyi slovnyk ukrainskoi movy, Kyiv, 2012, vol. 6, p. 160 .

[16] P.N. Donets, K tipologii kulturnyih kodov, Visnyk Kharkivskoho natsionalnoho universytetu im. V.N. Karazina, Romanohermanska filolohiia, Metodyka vykladannia inozemnykh mov 1002 (69) (2012) 6-9.

[17] V.A. Maslova, Duhovnyiy kod s pozitsii lingvokulturologii: edinstvo sakralnogo i svetskogo, Metafizika 4 (22) (2016) 80.

[18] L.V. Savchenko, Ierarhicheskaya model biomorfnogo koda kulturyi, Kultura narodov Prichernomorya 273 (2014) 170.

[19] A.V. Papsheva, Primenenie kategorii "kod" v lingvokulturologii, in: Izvestiya Samarskogo nauchnogo tsentra Rossiyskoy akademii nauk, 2010, vol. 12, 3 (2), p. 493.

[20] V.M. Savitskiy, E.A. Gashimov, Lingvokulturnyiy kod (sostav i funktsionirovanie), Moskva, 2005, p. 13.

[21] Etymolohichnyi slovnyk ukrainskoi movy, Kyiv, 1982, vol. 1.

[22] A.V. Olyanich, Kognitivnaya i lingvosemioticheskaya sistemyi glyuttonii: $\mathrm{k}$ razrabotke tipologii znakov gastronomicheskogo diskursa, Filologicheskie nauki v MGIMO 56 (71) (2014) 94.
[23] I.O. Derzhavetska, Hliutonichnyi dyskurs: leksykohrafichnyi aspekt, Odeskyi linhvistychnyi visnyk 4 (2014) 69.

[24] L.V. Savchenko, Model substantsionalnyih kodov kulturyi (na primere frazeosistemyi russkogo i ukrainskogo yazyikov), Kultura narodov Prichernomorya 275 (2014) 177.

[25] E.A. Gashimov, Angloyazyichnyiy lingvokulturnyiy alimentarnyiy kod: lingvosemiotika frazeologizmov kak edinits obraznoy semantiki, Filologicheskie nauki. Voprosyi teorii i praktiki 2 (68), part 2 (2017) 110-113.

[26] M.S. Nikishkova, Lingvokulturnyiy gastronomicheskiy kod V angloyazyichnoy potrebnostnoy kommunikatsii filologicheskie nauki, Filologicheskie nauki. Voprosyi teorii i praktiki, Tambov 12 (42), part II (2014) 124132.

[27] H. Sarach. Prirodno-landshaftnyiy kod kulturyi (na materiale russkogo i turetskogo yazyikov), dissertatsiya, Moskva, 2016, p. 37.

[28] U.Ia. Bylytsia, Kody kultury v obrazi liudyny v anhlomovnii kartyni svitu (na materiali komparatyvnoi frazeolohii), Naukovi zapysky Natsionalnoho universytetu "Ostrozka akademiia”, Seriia "Filolohichna” 62 (2016) 4144. 